\title{
Post-place branding as nomadic experiencing
}

\author{
George Rossolatos ${ }^{1}$
}

(C) Macmillan Publishers Ltd., part of Springer Nature 2018

\begin{abstract}
This paper introduces post-place branding in the context of the post-representationalist turn in marketing research by drawing on Deleuze and Guattari's (A thousand plateaus: capitalism and schizophrenia, University of Minnesota Press, Minneapolis, 1987) theory of nomadology. By engaging critically with fundamental concepts in the place and destination branding literature, post-place branding offers an alternative perspective to entrenched definitions of subjectivity, place, and event experiencing, by effecting a paradigmatic shift from processing monad to nomad, from event as symbolic structure to micro-events, from pre-constituted place to spacing in the process of deand reterritorializations. Post-place branding is illustrated by re-imagining the brand architectural components of the experiential events of 70,000 Tons of Metal and The Boiler Room. The analysis culminates in a metaphorical modeling exercise that draws nomadological guidelines for brandcomms' message strategy.
\end{abstract}

Keywords Place branding · Destination branding ·

Nomadology $\cdot$ Territorialization $\cdot$ Metaphorical modeling

\section{Introduction}

The principal aim of this paper is to re-imagine the concept of place branding and to conceptualize it within the broader contours of non-representationalist thinking that has been flourishing in marketing theory (Hill et al. 2014). Nonrepresentationalist thinking has been concerned with pre-

George Rossolatos

georgerossolatos123@gmail.com

1 Department of English, Kassel University, Kassel, Germany reflexive experiential possibilities and with pre-semiotic material assemblages that pass under the representationalist radar (Canniford and Bajde 2016). At the same time, nonrepresentationalist thinking has emphasized the purely affective dimension of experiencing, as flows of intensities, prior to sensibility's being subsumed under emotional categories as "sociological phenomena that are primarily played out within the dynamics of group life" (Boyns 2006, p. 270). As shown by Brennan (2004), the language of the flesh is not identical with the language of reason. Affect, sensing, and emotions work in parallel registers, but are not reducible to each other. The interdependency between affect and emotion, without this implying by any means the reducibility of the one to the other, constitutes a fundamental tenet for Deleuze and Guattari (1987): "Emotion and affect follow different logics and pertain to different orders" (Massumi 2002, p. 27). This fundamental distinction that informs the analytic of this paper has been obliterated in recent approaches to place branding. For example, Kavaratzis and Kalandides' (2015) perspective of the interactional formation of place brands puts consumer associations that spring from place representations at the heart of consumer experiences (also see Zenker and Braun 2017), thus being rooted in a cogito-centric and representationalist paradigm. The same line of thinking is followed in the experiential marketing perspectives put forward by Brakus (2008) and Brakus et al. (2009).

Complementary to the prioritization of affect, the concept of 'assemblage' has been central to the post-representationalist turn in marketing theorizing. The so-called 'assemblage theory' that was popularized by Latour (2005) and that has been applied extensively in consumer and in branding research (cf. Bjerrisgaard et al. 2012; Fredriksen 2014; Rokka and Canniford 2016) seeks to disrupt the Cartesian divide between objects and knowing subjects 
(Thompson et al. 1990). Moreover, it seeks to destabilize the essential(ized) properties of known objects in favor of relational networks whose constituent elements are always uncertain and open to changes (Canniford and Bajde 2016). This opening up of the concept of experience from knowing to being constantly re-assembled has enabled a unique focus on singular consumer experiences, and prospectively the advent of markets-of-one (beyond mass customization).

The concept of 'assemblage' was originally coined by Deleuze and Guattari (1987) as an integral part of their nomadological perspective that appeared in their seminal work A Thousand Plateaus. Although the notion of assemblage has found avid supporters in the respective marketing research stream, the conceptual armory of the nomadological perspective has yet to be applied. In an attempt to address the identified gap in conceptualizing place branding from a post-representationalist point of view, I therefore extend the applicability of Deleuze and Guattari's nomadological theory.

From a nomadological point of view, the capacity of the experiencing subject to constantly redefine its spatial contours has important implications for events' branding as non-place dependent destinations. Where does this perspective stand amidst the constantly augmenting place branding literature and what is its unique contribution? Although these questions will be elaborated throughout this paper, the following points hopefully attain to nurture at this introductory level a positive feeling of anticipation on behalf of the readers.

Events have been recognized as an indispensable aspect of place branding (Ashworth 2009) and destination branding (Hankinson 2015). At the same time, the ability of experiencing subjects to negotiate the meaning of events in a participatory fashion (Kavaratzis and Kalandides 2015) has added a qualifying dimension to the structure of place experiencing. The nomadological perspective, in turn, adds an extra dimension to the customization of events' experiencing and of participatory meaningful negotiation by putting under the microscope the ultimate bastion of experiencing: event experiencing as infinite singular assemblages in a predicament of consumer immersion that takes place on an affective and pre-subjective level.

The broader turn towards the experience economy (Pine and Gilmore 1998) has been coupled with the proliferation of agencies specializing in the design of involving and memorable brand experiences, an increase in investment in experiential marketing by advertisers and in the strategic role ascribed to experiential events in a branding panoply. In this context, not only music-related events have been proliferating, but the investment by advertisers behind bespoke experiential events (other than sponsorship) within music-related events has been mounting exponentially (Arrigo 2017). These trends are aligned with findings in academic research which suggest that experiential designs not only afford to attract more visitors, but also to engage prospects in low-involvement situations (Ober-Heilig et al. 2014).

Music as experiential consumption has been framed multifariously in the relevant literature. Relevant approaches have been focusing on how the meaning of music is shaped through promotional discourses including liveshows by drawing on a consumer psychoanalytic perspective (Rossolatos and Hogg 2013), on the consumption of lyrics (Askegaard 2010), on how ambidiegetic film music affords to advance dramatic meanings (Holbrook 2008), on the relationships between music, emotion, selfhood, and public identity (Hesmondhalgh 2008), on the strategic employment of music by exotic club dancers in their interactions with clients and club owners (Egan 2006), on the ways whereby the cultural meaning of pop music is negotiated by young consumers (Hogg and Banister 2000). Additionally, a vast inventory on the multifunctional effects of music in ad and brand discourses (e.g., Hung 2001; Kotarba 2003) has been accumulated over the years, also spawning the bespoke sonic branding perspective (Jackson 2003; Gustaffson 2015). Music-related events, such as festivals, constitute an indispensable aspect of the experiential economy, not only by dint of their unique multisensorial orientation and their interactive nature (Smilansky 2009), but also as platforms for staging parallel experiential events that afford holistic brand and interbrand experiences. Given the importance of music-related events in the experiential economy, this study draws on two music-related events as destination brands: the heavy metal cruise 70,000 Tons of Metal and the mobile DJ event The Boiler Room. These events stand out and are particularly relevant for this study as they comprise the element of mobility (particularly important for a post-place perspective). Especially in the case of 70,000 Tons of Metal, the event experience is structured as a multi-layered whole of themes within themes (cf. Firat et al. 2011). In this context, music per se is treated as part of a broader cultural space or branded space (Sonnenburg and Baker 2013) whose components and interaction in a metaphorical modeling schema will be sketched out.

Pursuant to the above precursory remarks, this paper is structured as follows: Initially, the key tenets of the nomadological perspective are laid out, with an emphasis on the post-representationalist view of subjectivity, the role of affect in the constitution of places and events as prereflective experiencing, and de/reterritorialization as processes whereby the meaning of place is constantly negotiated. The exposition of the evoked perspective is followed by a more focused analysis of the key areas where 
nomadology seeks to make contributions, while engaging with the extant literature. Then, the research design that is adopted in the empirical prong of this study for illustration purposes is laid out, followed by a description of the brand architecture of the two focal music events, informed by place branding conceptual models. The articulation of the two events from a nomadological prism is subsequently reimagined by highlighting experiential aspects that have been suppressed in territorialized brand discourse. Finally, the implications for events' brandcomms planning as postplace experiential brands are discussed by addressing the identified gaps in the light of a metaphorical modeling exercise. The exercise focuses on 70,000 Tons of Metal and aims at highlighting the possibilities of nomadic experiencing. The paper concludes by wrapping up the key contributions of nomadology in the extant literature, while discussing the benefits that stem from its application in place brand panning.

\section{The nomadological perspective}

In order to appreciate the contribution of the nomadological perspective in the place branding literature as an opening up to a post-place branding territory, it is crucial that major differences between nomadology and fundamental premises of place and experiential branding approaches are put under the microscope. Here, I concentrate on differences alongside the concepts of subjectivity, affect, the structure of experience, and the experiential constitution of space/place. Key concepts of Deleuze \& Guattari's nomadological perspective are presented in a contrastive fashion vis-à-vis the place branding literature in order to highlight subtle differences and to render the contributions of the perspective more palatable.

\section{Pre-subjective experiencing: from monads to nomads}

Deleuze and Guattari diverge markedly from the bulk of consumer theoretic approaches that rest on an ego-centric view of subjectivity and that posit the motivation paradigm at the center of consumption experiences. Brand experiencing is an integral aspect of place branding strategic management models (Hankinson 2009, 2015; Anholt 2010; Hanna and Rowley 2011, 2013; Da Silva Oliveira 2016). The impact of the motivation paradigm in accounting for how meaning is generated from consumers' engagement with brand experiences is reflected in premises such as the following: "we define personal resonance as the goodnessof-fit between a brand's architecture of claimed meanings and the meanings the consumer seeks in his/her personal life" (Fournier et al. 2008, p. 40). On the contrary, Deleuze
\& Guattari assume as the vantage point of experiencing the pre-reflective domain of pure affectivity and, secondarily, open up experiencing to assemblages between the subject of affectivity and the 'exteriority' that conditions it. "Flows of intensity...have replaced the world of the subject...There is no longer a Self [Moi] that feels, acts, and recalls; there is 'a glowing fog, a dark yellow mist' that has affects and experiences movements, speeds" (Deleuze and Guattari 1987, p. 162). On an epistemological level, this point of departure affords to dislodge subjectivity from the constraints of ego-psychology, and to unleash experiencing towards constantly proliferating singularities. The singular, non-repetitive nature of these experiences is defined by a meltdown of dominant discourses, a radical openness towards "a free form of semiosis" (Parr 2010, p. 240), and the possibility of subaltern experiencing of 'events.' In this manner, the meaning of an event shifts from the symbolic determinants of its staging (e.g., a music festival and its signs) towards the non-replicable and singular experiencing by individuals at the pre-cognitively constituted level of affect. This is the level of 'flows of intensity' as termed by Deleuze and Guattari.

The importance of placing flows of intensity rather than the subject at the center of experiencing has been rendered succinctly by Govers and Go (2009, p. 137) as follows: "although in flow experiences clear goals and quick and unambiguous feedback on performance are needed, the goals are often just an excuse to make the experience possible." In lieu of the subjectivity-centric rationale that permeates the experiential consumption and the place branding literatures, Deleuze \& Guattari envision an exit from "the regime of subjectification or subjection and against the stratification of desire flow within a site of individuation [where] each of us has then to semiotize oneself" (Voisset-Veysseyre 2011, p. 5). Their perspective, thus, may be said to be a precursor for the full-fledged materialization of 1-2-1 marketing.

At this level, the individual as monad (or as the omnipresent processor of external stimuli) is viewed as a nomad, that is as a pre-subjectively constituted entity at the intersection between pure matter (or absolute exteriority) and the subject as experiencing correlate. The fundamental distinction between monad and nomad consists in that the latter is not viewed as a fully formed subject (the case of the monad), but as an assemblage that is relationally, provisionally, and situationally constituted in its encounter with matter as absolute exteriority. Affect stems from this encounter, thus being radically different from emotions that have been contaminated by the structure of subjectivity or the monad. 


\section{The nomadological structure of experience}

As regards the structure of experience, Caru and Cova (2003) problematized the diffuse employment of the notion of consumption experience through a cross-disciplinary analysis that culminated in a fundamental distinction between consumer experiences and consumption experiences (cf. Rossolatos 2015a). The difference lies in the not necessary dependence of the latter on the market as relationships of exchange. In the review process, Caru and Cova (2003) unearthed various interesting framings, converging on a distinction between ordinary and extra-ordinary experiences that range from ordinary to religious experiences. The vast majority of scrutinized perspectives by Caru and Cova (2003) adopt a positivistic line of inquiry, while drawing on expected consumer benefits and perceived outcomes from the engagement with consumption experiences.

Most relevant for the analytic at hand is the employment of the concept of 'flow' by Arnould and Price (1993) which is assimilated by the authors to ecstatic religious experiences. This approach is the polar opposite to Deleuze and Guattari's concept of flows of intensity, as above defined. Deleuze and Guattari opt for the de-sublimation of flow, that is its release from any 'spiritual' domain. In fact, their approach celebrates levels of intensities as experienced contextually and situationally, especially in the face of otherwise mundane experiences and not at all dependent on a spiritual order. Intensities flow differentially in moments of consumption of even provisional assemblages, such as the ephemeral constellations of fashion where every object may be resemanticized according to whim (see introduction on free-form semiosis). Such constellations constitute veritable instances of what Firat and Venkatesh (1995) described as a re-enchantment of consumerism and liberatory post-modernism, a standpoint that is well aligned with Deleuze and Guattari's orientation. This is precisely the level of experiencing where the nomadological perspective offers a different and highly nuanced take in the face of the extant literature on experiential and place branding. As remarked in the introduction, at this level event experiencing is seen as infinite singular assemblages in a predicament of consumer immersion that takes place on an affective and pre-subjective level. The nomad does not own the experience (in contrast to the monad), but is immersed in the experience at a pre-subjective, highly singular, and prototypically affective level.

This allegedly radical empiricist standpoint re-unites consumption with its 'subject' at the cross-roads of the materiality of signifiers. Signifiers are not conceived only in their intangible dimension (as representations that constitute the groundwork for edifying subjective associative networks, pace Kavaratzis and Kalandides 2015), but first and foremost in their materiality as affective constellations that constitute the subject as substratum of experiencing. In this context, the subject is posited as minimal unit of experiencing only heuristically (Delanda 2006b).

Having, thus far, defined the crucial difference between subjectivity, as customarily approached in experiential and place branding approaches and the nomad, as viewed from Deleuze and Guattari's nomadological perspective, and analyzed their respective differences in the structure of experience, let us now turn to the final part of the conceptual exposition concerning how space/place is approached within nomadology.

\section{The space of nomadology: from striated to smooth by way of de- and reterritorializations}

"The space of nomad thought is qualitatively different from 'striated' or gridded space. Movement in it [my note: striated space] is confined as by gravity to a horizontal plane and limited by the order of that plane to preset paths between fixed and identifiable points. Nomad space is 'smooth' or open-ended" (Massumi 1996, p. 6). In terms of place branding, striated space is equivalent to the symbolic space of a place brand. This is, for example, the symbolic structure of a nation or a city or a music event (e.g., the Reading Festival). It consists of a name, a logo, codified communicative cues, and so forth. Smooth space concerns the freedom of the experiencing nomad to negotiate the meaning of striated space as it moves on its territory (Patton 2005). These movements constitute singular (non-replicable and non-symbolic) lines-of-flight, as termed by Deleuze and Guattari (1987). Throughout these movements, striated space is deterritorialized (i.e., divested of symbolic meaning) and at the same time reterritorialized (i.e., invested with new and subaltern meanings based on situational assemblages of the experiencing nomad with the materiality of signifiers). Smooth versus striated space may be schematically portrayed (Fig. 1) as progressive levels of opening up the meaning of place from de- to reterritorializations.

The distinction between smooth and striated space has important implications for place branding (even as space branding or branded spaces (Sonnenburg and Baker 2013), as will be displayed more thoroughly in the ensuing section) insofar as the more amenable to reterritorializations an event, the less it is preconstrained by place determinants. Hence, an event is not predefined by striated space (e.g., the name of the place, the name of the streets, the architecture), but at the smoothness end of the continuum it is radically open to resemantization and meaningful negotiation. The nomad is open to exteriority not as preconstituted place, but as mutually conditioning space (i.e., between the inside and the outside), a vague identity between free flowing matter and thought (Deleuze and 
Fig. 1 Striated versus Smooth space as a continuum of reterritorializations

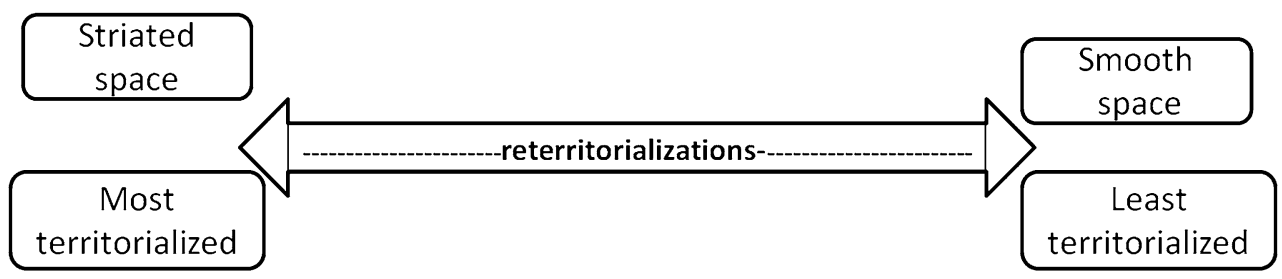

Guattari 1987, p. 408). This is the space of nomadic thinking.

Movement in smooth space is coupled with an openness to ever new assemblages, reterritorializations, and with pre-reflexive flows of intensity. These defining characteristics of nomadology that are portrayed in Fig. 2 will be constantly elaborated, refined, and rendered more palatable as our conceptual discussion and further exemplification progresses.

In a nutshell, the nomadological perspective has germane conceptual implications for place/destination branding primarily on two levels, namely on subject/ identity formation and on the spatialization of experience. Both axes are concerned with radical openness to preperceptual sensibility that is beyond subjectivity, while being place-independent: "while the normative subject experiences the perceptible reality of conventional space and time, the nomadic subject resonates with the imperceptible relations implicit in her experience" (Lorraine 2005, p. 170).

\section{The contributions of nomadology to the place branding literature}

Pursuant to the exposition of fundamental premises of the nomadological perspective in the previous section, here a further elaboration is offered of these premises vis-à-vis the extant literature on place branding. The aim is to appreciate the differential benefits of nomadology as post-place theorizing in the construal of events as singular experiences.

\section{Place is construed through pre-reflective experiencing on a plane of virtuality}

In the light of the already massive literature on the subject, asserting that place and destination branding concern physical places (i.e., non-discursively and narratively mediated), rather than cultural, themed spaces (Firat et al. 2011; Campelo 2015), is a truism (Abousnnouga and Machin 2011; Hess-Luttich 2016; Lagopoulos 2009). "Space may be considered as a cultural text, or rather as cultural texts" (Lagopoulos 2009, p. 171) as "different spaces with different practices by different agents superimposed upon it" (Sonnenburg and Baker 2013, p. 15). "Place is the more physical dimension of a branded space which becomes a branded place through branding and perceiving. Space is the more social dimension of a branded space which emerges through spacing, synthesizing and interpreting" (Sonnenburg and Baker 2013, p. 16). A similar conceptualization is almost dominant in fields such as discourse analysis and urban geography: "Space and discourse are increasingly enmeshed and mutually constitutive" (McIlvenny and Noy 2011, p. 147). From a postmodernist point of view, space is inherently metaphorical (Lagopoulos 2009). The inherently polysemic experiential consumption of 'place' has been exacerbated by the increasing empowerment of consumers in co-creative interpretive engagements.

Fig. 2 Place and identity from striated to smooth space in a continuum of reterritorializations
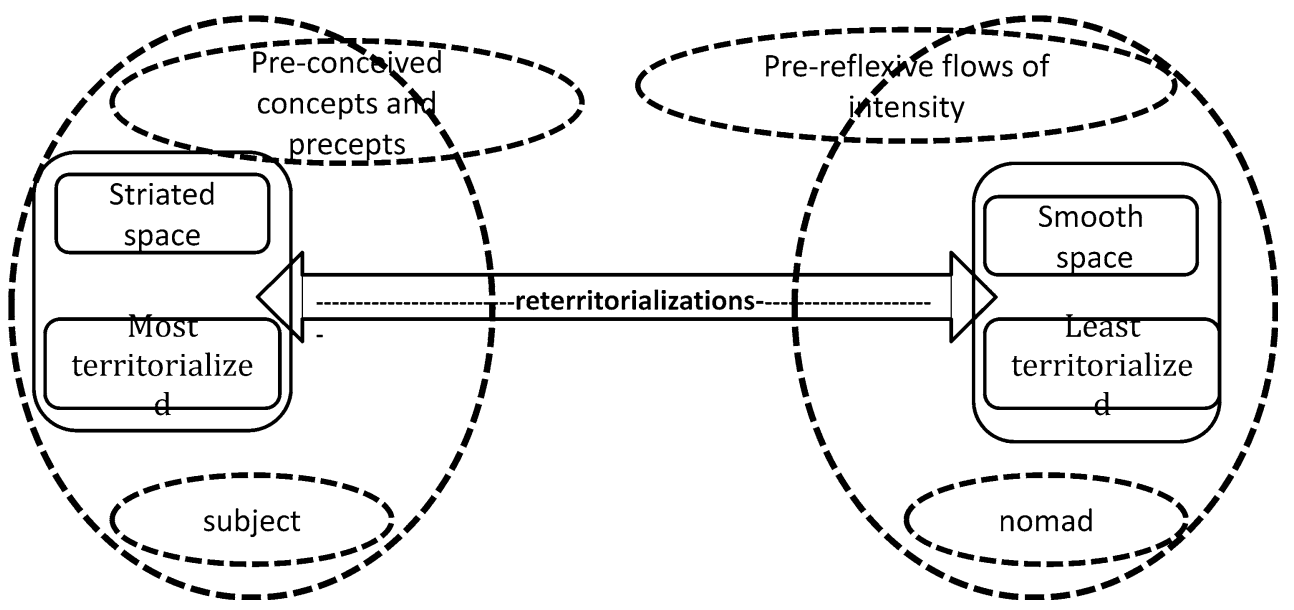
The fundamental distinction between place and space, from Deleuze and Guattari's nomadological angle, resonates with the standpoint that any object rests on a plane of virtuality insofar as it can be experienced in infinite configurations in a process of becoming. There is no fixed meaning in place but the meaning ascribed to it situationally by nomads. This standpoint introduces a unique perspective in the place branding literature as against how place is negotiated by social groups and individual monads.

This nomadological contribution frees place meaning from symbolic impositions while reorienting it towards unsublatable singular experiences. The challenge, then, is to coin experiential events in a post-place consumptive terrain that retain the aspect of virtuality as radical openness to non-localizable meaning. The nomadological challenge has not been met yet by models put forward in the place branding literature that abide largely by a cogitocentric rationale. This rationale posits the experiencing subject, and concomitantly the processes of perceiving, synthesizing perceptions, and interpretation at the center of consumption experiences. As was shown in the previous section, the perspectival shift from monad (subject) to nomad is an essential pre-requisite for experiencing events not as a plenum of perceptions against pre-constituted symbols that are conditioned socially (which is assumed axiomatically as a point of departure, for example, in Sonnenburg and Baker 2013), but as pre-symbolic flows of intensities that open up new interpretive possibilities at a plane of virtuality. This task will be undertaken later in the metaphor modeling exercise.

\section{The many within the one: from the brand architecture of 'the' event to events/affects as singular lines-of-flight}

The above-mentioned symbolic pre-constitution is exponentially exacerbated in the case of nation, city, area branding (cf. Balakrishnan and Kerr 2013) that is marked by an a priori imposition of a brand identity as limited and stringent set of branding components (e.g., food and beverages, dresses, customs, population habits) and interpretive constraints by a dominant state or area ideology (Govers and Go 2009, pp. 63-64). Nation branding discourse, in Deleuze \& Guattari's terms, is strongly territorialized (cf. Fig. 1), leaving little room for creative interpretive appropriation and singular lines-of-flight. Surely this is a double-edge situation as otherwise evoking generic consumer benefits in a projected place brand discourse will risk dilution in the face of competition in the era of the competitive state (Balakrishnan and Kerr 2013). However, contrasting nation branding with less constrained and more amenable to deterritorialization discourses, such as event branding, allows for an appreciation of the wider experiential and interpretive possibilities endemic in the latter.

This contrast assumes even more cogency within a nomadological purview where the 'event' takes on a specific meaning as 'events/affects' (Deleuze and Guattari 1987, p. 408). This meaning concerns primarily, that is before its regimentation in a striated discourse, the encounter between the flow of matter and a living organism that senses pre-perceptually (that is before ascribing a regimented emotional descriptor to an affective constellation), and by implication pre-reflexively. The 'event' is the in-between ('intermediary': Deleuze and Guattari 1987, p. 410) of this experiential encounter, an in-betweenness that produces 'its' counterparts, that is subject and matter (and not vice versa).

Nomadic thinking opens up the name (brand identity) and its components (branding elements) to their affective substratum while addressing how flows of intensities that impact a pre-subjectively construed nomad rather that a rigid structure called subject may be experienced. The striated brand architecture is edified on the smooth space of events-affects that await to be semanticized in individual lines-of-flight. Thus, the name of an event as customarily conceptualized (e.g., 70,000 Tons of Metal or Boiler Room, in our case), consists of a potentially infinite number of situational 'threshold events' that lie dormant at the plane of virtuality. Nomadological thinking aims at actualizing these micro-events from the plane of virtuality, as experiential reterritorializations in smooth space, and hence as non-place dependent (that assumes striated space as conditional).

\section{Branding post-place events as destinations without destiny}

It is prudent at this juncture to incorporate destination branding in the post-place conceptual scope as its greater flexibility compared to place branding fits the perspectival shift of the meaning of 'place' as non-place dependent 'event.' This fit has been recognized on a broader level in the often interchangeable employment of place and destination branding (see Morgan et al. 2011). As stressed by Moilanen and Rainisto (2009, p. 112), "the spectrum of destinations is enormous. At the one end are compact destination products such as theme parks and spas [...] At the other end of the spectrum are groups of countries or whole continents." On a narrower level, this fit is reflected in the recognition of events as an integral part of place and destination branding (cf. 'events' as positioning part in the 7-step destination branding process coined by Baker 2007 and the extensive review of place branding models in Hanna and Rowley 2013). 
According to Deleuze and Guattari (1987, p. 409), the itinerant as follower of a destination path is a form of nomadism. Two types of itinerancy are identified: "intuition in action" (Deleuze and Guattari 1987, p. 409) and "rotation" (Deleuze and Guattari 1987, p. 409). The latter conforms to the interchangeable employment of place with destination in the literature insofar as it implies a specific name or toponym (place-name) as place of departure and a destination place-name. Hence, this type constitutes an itinerary in striated space. The former type of an active agent in itinerancy as not pre-destined destination is the nomad who floats 'in' absolute exteriority, in quest for a smooth space to anchor provisionally prior to being rereleased to floatedness.

The nomadological treatment of destination contributes to the destination branding literature by viewing experiential space as pre-territorialized, and hence the experiencing nomad as floating in space. A branded event, in such a post-place predicament, consists of singular microevents as provisional anchorings in a constant state of floatedness.

\section{From singular experiencing to brand communications: The challenge of metaphorical modeling as simulating device}

The post-representationalist perspective of nomadology is not bereft of challenges as regards its applicable dimension. Despite the fact that romanticizing the markets is a legitimate speculative exercise and much needed for opening up liminal zones in striated space, and that academic theory does not necessarily walk hand-in-hand with marketing practice, stressing the applicable dimension of nomadology in the domain of place branding is not a fruitless endeavor. In any case, it should be borne into mind that the majority of planning models put forward in the relatively nascent stream of place branding rest on a theoretical level, while awaiting empirical validation in confirmatory studies, as noted by Hanna and Rowley (2013).

In order to address the applicable dimension of nomadology as post-place experiencing, though, we must consider how the envisioned level of events' pre-subjective experiencing may be bridged with fundamental planning and execution exigencies of brand communications. Such considerations impinge on a variety of tasks, ranging from message and media strategy to budgetary and logistical aspects, and are significantly complicated once the focus of attention shifts from a single medium to an IMC perspective. Here I shall be concerned solely with message strategy as the primary consideration concerns how nomadic experiencing may be accommodated in a brand architecture that rests on brand symbolism.
Although the conceptual exposition thus far has been geared towards demonstrating the benefits of opening up events' experiencing at the level of singular lines-of-flight, most likely the prospect of incorporating this level of experiencing in a brand promise and in advertising copy looms like an unattainable task. This is attributed to an abyss of non-communicability that lurks between presubjective experiencing and brandcomms' target audiences that customarily consist of message-processing subjects rather than nomads.

Although Deleuze and Guattari's radical pragmaticism does not reject the intimate imbrication of individual with social texts, in principle these two texts appear to be irreconcilable. On the one hand, we are confronted with the 'subject'-related sub-task: experiencing symbolically constituted events as reterritorializations of micro-events, that is as 'encounters' in between affect and a pre-semiotic materiality that is experienced in lines-of-flight; in a nutshell, as a brand promise of potentially infinitely proliferating 'events' that mitigates not only the definition of brand identity (which conditions brand promise), but the very logical principle of non-identity that sustains brand identity in the first place. On the other hand, we are facing the 'place'-related sub-task: branding these experiences as micro-destinations in smooth space, while at the same time rendering them part of symbolically constituted events' striated promotional discourse (that partake of an identifiable brand identity as experiential umbrella).

The reconciliation of these two sub-tasks is the objective of metaphorical modeling as will be illustrated in the final section. Suffice to point out at this stage that this objective may be attained communicatively on a metaphorical level as a simulation of singular experiencing. By definition, the space that is opened up by a metaphor is neither symmetrical with nor commensurate to the actual space of experience. The transportation to an evoked experiential space is effected by virtue of the simulating capacity of metaphors. The simulating power of metaphorical modeling abides by the post-representationalist orientation of the nomadological perspective insofar as it does not reduce event experiencing to multiple subjective associative networks (relating to identifiable representations as place brand symbols), but assimilates the infinitely singular to an ideal type of floatedness in non-striated space and absolute openness.

As stressed in Sect. 2, although nomadologically the experiential consumption of events is not primarily framed linguistically, yet in order to allow for its communication, their linguistic investment is necessary. But insofar as the plethora of 'events' making up the overarching event are experienced as flows, encounters, and non-places, the onomatology of coded micro-experiences always already refers metaphorically to a multiplicity of encounters as 
'events/affects' (Deleuze and Guattari 1987, p. 408) or as "non-signifying signs making up a territorial chain" (Hughes 2008, p. 90). The notion of 'event' actually refers to many pre-subjective layers prior to its discursive crystallization in brand communications. At the same time, the linguistic descriptors making up experiential events constitute assemblages that are more or less amenable to reterritorializations for individual nomadic subjects and collectivities. Individual descriptors shelter flows of intensities. The same holds for individual lines-of-flight, a key aspect of experiential events' customization, and the attainment of truly singular 1-2-1 marketing (rather than mass customization as its ideational counterpart).

Potent metaphors refer obliquely to such events/affects that are communicated either as ontological or as orientation metaphors, depending on the experiential scope of each metaphor (e.g., the relationship of 70,000 Tons of Metal to a subordinate micro-event, such as a casino or a karaoke).

This permeating metaphorology has been termed by Zaltman and Zaltman (2008) Metaphoria, comprising depth and surface metaphors: "deep metaphors are enduring ways of perceiving things, making sense of what we encounter, and guiding our subsequent actions" (Zaltman and Zaltman, 2008, p. xv). Furthermore, as shown by Kitchen (2008), the interpretative turn in marketing theory and practice spawned skepticism towards fundamental terms such as 'product life-cycle' and 'market segmentation' as being vacuous (in terms of actual referents). Additionally, the constructionist nature of such terms as tropical devices, rather than realistic descriptors has been amply noted (e.g., market segmentation as a theoretical abstraction from a plethora of empirical particulars). In these terms, metaphorical modeling is not something new in marketing theory and practice, but in fact concerns the fundamental process whereby marketing terms are conceptualized and subsequently operationalized. The same holds in the case of employing metaphorical modeling as a simulating device.

Moreover, the very imagery included in brandcomms has been repeatedly shown to be producing pragmatically the intended effects of advertising discourse (e.g., introducing a lifestyle or changing consumption habits), rather than representing a given market reality. As notably argued by Baudrillard (1994), on a more fundamental ontological level and especially in the context of a highly mediatized global village, reality is the effect of simulation, a simulacral self-contained epiphenomenon, rather than a representational nexus (also see Rossolatos 2014 for an analysis of Deleuze's take on the concept of simulacrum, and Dholakia and Reyes 2013 on simulacrum as process). Metaphorical modeling, as will be displayed in greater detail while discussing the nomadological reframing of
70,000 Tons of Metal, constitutes a prominent case of linguistic simulation whereby reality is produced as linguistic structure, according to Lakoff and Johnson (1980).

\section{Research methodology}

In order to illustrate the nomadological perspective, a qualitative research design was adopted by drawing on a sample of $N=54$ video reviews and written reports about 70,000 Tons of Metal and Boiler Room events (see Table 3 in Appendix). In terms of data collection, the corpus was sourced largely from the events' official web-pages and youtube channels, spanning the entire period during which they have been running.

The analysis was geared towards (i) identifying the brand architectural building blocks of the two events, (ii) identifying how the events' experience is framed in the promotional discourse of the events' organizers, in the written reports produced by cultural intermediaries (i.e., music journalists), in the participating band members' and the end-consumers' event associations, and (iii) looking for traces of nomadological experiencing beneath the territorialized discourse that rests largely on the symbolic apparatus of the brand architecture.

All video data and written reports were analyzed by using the qualitative discourse analytic software ATLAS.ti (cf. Figs. 3, 4). Each file (videos and texts) was saved as a primary document in the project's hermeneutic unit. Prior to annotating with memos and coding the data, the reviews were read and the videos were watched several times in order to obtain a primary feel for the data. The data were coded through an open coding iterative procedure. Memos featuring interpretive insights were regularly annotated to the respective codes (Fig. 3). As soon as the coding procedure was complete, consolidated reports were produced (Fig. 4). The analysis drew on the inferential operations of categorization, abstraction, dimensionalization, and integration (Spiggle 1994). Emergent thematic territories were actively sought both in the projected brand discourse and in consumers' interpretations of the events' experience.

\section{Discussion of research findings}

\section{The brand architecture of the two music events (70,000 Tons of Metal, Boiler Room)}

In this sub-section, the branding components of the two focal experiential events will be displayed with a triple orientation: first, in order to offer a descriptive account of how these events have been discursively shaped by their brand owners with an emphasis on identifying how 


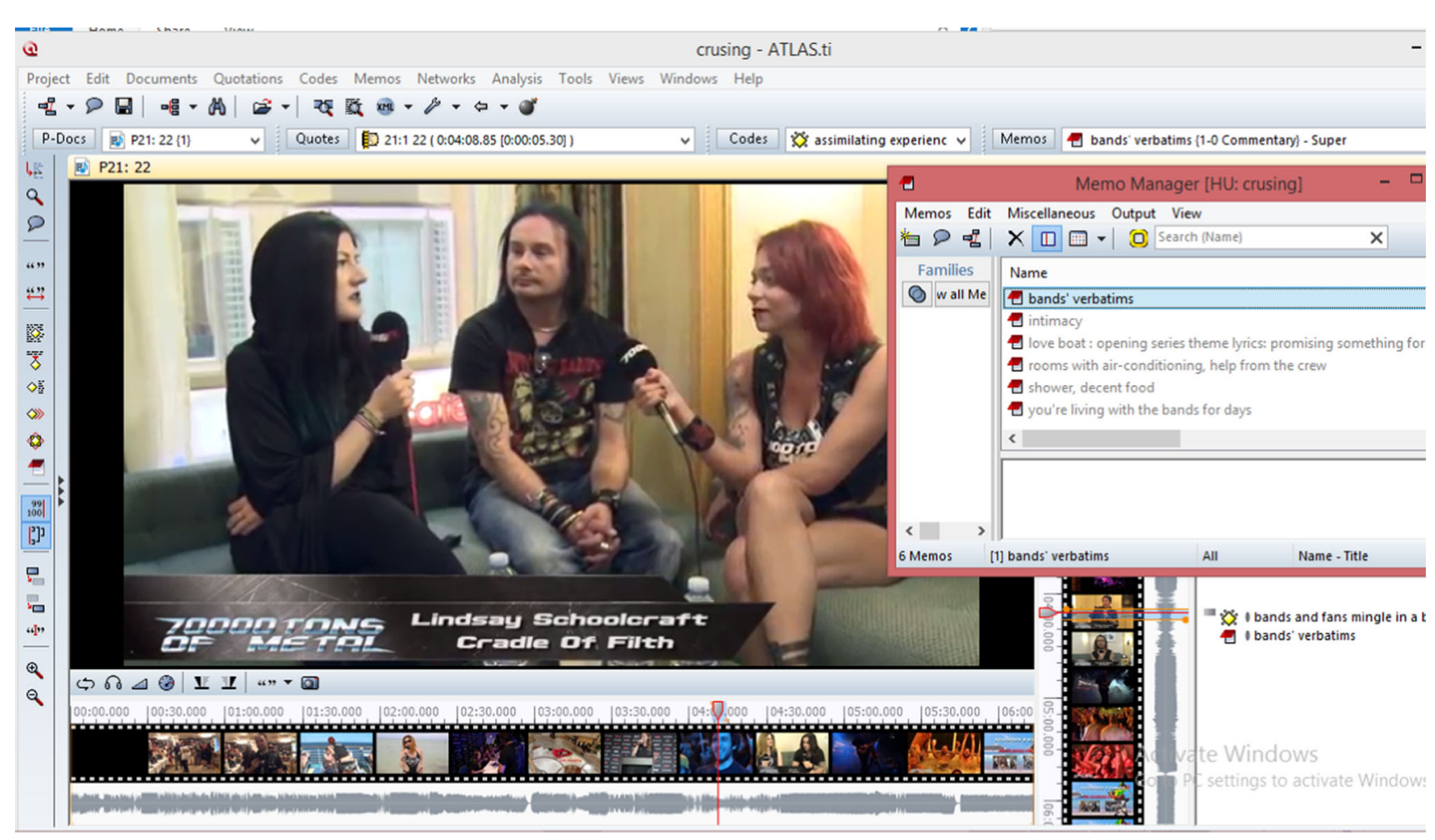

Fig. 3 Screenshot from the ATLAS.ti CAQDAS workbench that was used in the analysis of the 70,000 Tons of Metal and Boiler Room verbovisual data (cf. Rossolatos 2013)

Fig. 4 Example of ATLAS.ti consolidated output of codes and memos
Code: consumer associations- points of difference vs standard festivals $\{2-0\}$

P16: 12 - 16:2 [12] ( 0:01:58.69 [0:00:11.68]) (Super)

Codes: [consumer associations- points of difference vs standard festivals] No memos

P20: 21 - 20:2 [21] ( 0:01:49.83 [0:00:06.57]) (Super)

Codes: [consumer associations- points of difference vs standard festivals]

Memos: [shower, decent food]

\section{Code: disruption of backstage frontstage striated territorialization $\{2-0\}$}

P 2: 28 - 2:1 [Would have liked to join the g..] (1:1017-1:1151) (Super)

Codes: [bands engaging in experiential activities] [disruption of backstage frontstage striated territorialization] No memos

Would have liked to join the guys from Pretty Maids at the blackjack table (Ronnie Atkins and Ken Hammer seemed permanently entrenched

P10: 1_6.pdf - 10:1 [it's like everyone has a backs..] (1:288-1:327) (Super)

Codes: [disruption of backstage frontstage striated territorialization]

No memos

it's like

everyone has a backstage pass descriptors function metaphorically in a non-nomadological communicative setting as territorialized space; second, from a nomadological point of view, in order to identify what sort of experiences are suppressed in territorialized brand discourse; and third, to re-imagine through metaphorical modeling how the events as social brand texts may be re-articulated while benefiting from their nomadological reframing. 
In line with the place branding literature, the two focal events' brand building blocks as territorialized signs in striated space will be outlined by recourse to the archival video materials and written reports of our corpus (Table 3 in Appendix) as per the above research design.

According to Govers and Go (2009, pp. 50-51) place branding elements consist of geography, climate and history, physical appearance (e.g., landscapes), religious and cultural values embodied in language, colors, symbols (names, logos, emblems such as flags, costumes, folk dances, or maps), behavioral aspects, and communication. The exposition of the two events' brand architecture is deployed here in a back2back fashion. The objective is to highlight their similarities and differences within the broader contours of post-place branding and nomadological experiencing.

70,000 Tons of Metal has been running consecutively each summer since 2011. It concerns a 5-day cruise that hosts a 4-day around-the-clock open-air heavy metal festival plus one day of recreational activities at a select Caribbean destination. Complementary to the festival, the experiential gestalt of 70,000 Tons of Metal features a plethora of micro-activities and micro-destinations that spread over 15 decks, such as a golf simulator area, a climbing wall, a library, a sports court, a spa and fitness center, a solarium, various cafes, bars and restaurants, as well as various stages, over and above the main open-air one. Experiential micro-events include an autograph session, pillow-fighting, a belly-flop pool contest. It hosts on average 60 live acts on each sold-out cruise, while it attracts every year 3000 heavy metal fans from allover the world. This is a veritable case of destination branding and, as will be shown, of post-place branding with enormous experiential potential from a nomadological point of view.

The Boiler Room is a globally mobile and versatile artsoriented conceptual umbrella whose artistic core is music. It hosts largely DJ acts spanning a colorful spectrum of sub-genres, from dubstep to techno and from hip-hop to avant-garde electronica who perform their sets in select clubs allover the globe, but also live acts. Some of the Boiler Room events have been sponsored (e.g., by RayBan, Ballantine's, Audi), while on a select few occasions major technological-cum-lifestyle events have been hosted under its umbrella, such as Google Pixel's Virtual Dancefloor. The brand mission of the Boiler Room is to create a global cultural space for electronic musical invention and the emergence of new trends which is the main driver behind the penchant for hosting upcoming, rather than mainstream DJ's.

As regards the brand names that underpin expressively the events, while being a reflection of their brand promise, we notice that 70,000 Tons of Metal functions on two levels. On a denotative level, it refers to the actual material used for the construction of the ship (metal), while on a connotative level it emphasizes hyperbolically heaviness as an embedded trait of heavy metal music. The brand name Boiler Room suggests a branded space that is defined by the process of boiling, not literally, but metaphorically, as a nominalized verb, pace Fairclough (2004). This nominalization suggests an osmotic space where cybernetic heat among participants reaches its maximum, thus forcing the participating bodies to coalesce in a non-identificatory ('boiling') and multidirectional space. The osmotic connotation of the Boiler Room is also suggestive of the event's orientation as cultural space for emergent patterns generation.

From an experiential point of view, both events are marked by a direct communication route between performing artists and audience. Although this is a standard trait of clubbing culture, in the case of heavy metal artists the breakdown of the spatial demarcation between front and backstage and the intermingling of some allegedly high-ranking bands (e.g., Anthrax, Slayer) with the audience on board is quite an innovative approach: "For artists and fans alike, the trip of a lifetime"; "it's like everyone has a backstage pass" (Table 3 in Appendix, 1). On an equal footing, the incidence of rooms, the opportunity to shower, and to have proper meals are perceived by consumers as valuable points of differentiation versus customary festivals (App. 1, 12, 21). This reflects the cultural value orientation of 70,000 Tons of Metal as an all-encompassing cultural space of openness to something greater than heretofore regimented divisions, a third realm that re-unites sedimented spacings between the inside and the outside of cultural production (cf. Rossolatos 2014). In this case both consumers and artists are imbricated in the wider schema of reterritorialization and flow that transcends symbolically demarcated boundaries.

The rest branding components of the two events from a place branding perspective are charted in Table 1, while the points of parity and differentiation between the two events are displayed in Table 2.

In the following sub-section, the main gaps from a nomadological point of view are identified regarding how the two events are experienced, as may be gaged from the archival data at hand, prior to proceeding with suggestions for their reframing in metaphorical modeling terms.

\section{Nomadologically addressing suppressed brand experiences}

To begin with, flows of intensity and reterritorialization apply to both events. However, they are not reflected adequately either in the events' brand communications, or in consumers' perceptions about the events. This is especially the case for 70,000 Tons of Metal which presents 
Table 1 Place branding components for 70,000 Tons of Metal and Boiler Room

\begin{tabular}{|c|c|c|}
\hline Branding component $^{\mathrm{a}}$ & 70,000 Tons of Metal & Boiler Room \\
\hline Physical appearance & $\begin{array}{l}\text { A } 15 \text {-deck boat featuring branded spaces for different } \\
\text { activities }\end{array}$ & Clubbing venues on a global scale \\
\hline Cultural values & $\begin{array}{l}\text { Dominant culture: Global heavy metal identity; ancillary } \\
\text { cultural values demonstrated by participating fans (cf. } \\
\text { Table } 3 \text { in Appendix): national cultures, male bonding }\end{array}$ & Clubbing culture \\
\hline Colors (ship/venues) & Red, black, and white (cruise ship) & Variable depending on the clubbing venue \\
\hline $\begin{array}{l}\text { Colors (brand visual } \\
\text { identity) }\end{array}$ & Sky blue (graded) & $\begin{array}{l}\text { Yellow capital fonts within a circular shape on a black } \\
\text { background }\end{array}$ \\
\hline Costumes & $\begin{array}{l}\text { Metal brand ambassadors: black bikinis with visual } \\
\text { identity in white fonts }\end{array}$ & No particular style \\
\hline $\begin{array}{l}\text { Behavioral } \\
\text { aspects/coded } \\
\text { communications } \\
\text { among participants }\end{array}$ & $\begin{array}{l}\text { Loud crowds, intense experiencing, devil horns kinetic } \\
\text { signs, headbanging kinetic signs, mosh pit dance } \\
\text { kinetic signs. }\end{array}$ & $\begin{array}{l}\text { Intense experiencing (where upbeat dance genres are } \\
\text { concerned), dance kinetic signs among participants, } \\
\text { kinetic interpellation between DJ and audience }\end{array}$ \\
\hline
\end{tabular}

${ }^{a}$ As per Govers and Go (2009, pp. 50-51)

Table 2 Points of parity and differentiation between the experiential events of 70,000 Tons of Metal and Boiler Room

\begin{tabular}{|c|c|c|}
\hline & 70,000 Tons of Metal & Boiler Room \\
\hline \multicolumn{3}{|l|}{ Points of parity } \\
\hline Overall experience & Pre-individuated flows of intensity; ecstasy & Pre-individuated flows of intensity; ecstasy \\
\hline $\begin{array}{l}\text { Role of communication } \\
\text { versus experience }\end{array}$ & $\begin{array}{l}\text { Branding; generation of excitement about the event; } \\
\text { drive traffic/generate sales }\end{array}$ & $\begin{array}{l}\text { Branding; generation of excitement about the event; } \\
\text { drive traffic/generate sales }\end{array}$ \\
\hline $\begin{array}{l}\text { Importance of 'place' to } \\
\text { the generation of event } \\
\text { meaning }\end{array}$ & $\begin{array}{l}\text { Minimal; the event is afloat, conditioned by constant } \\
\text { mobility }\end{array}$ & Minimal; global mobility lies at the heart of the event \\
\hline \multicolumn{3}{|l|}{ Points of differentiation } \\
\hline Overall experience & Exceptional; once in a lifetime & Ad hoc, similar to any ordinary clubbing event \\
\hline $\begin{array}{l}\text { Role of communication } \\
\text { versus experience }\end{array}$ & $\begin{array}{l}\text { Actual experience overrides the importance of brand } \\
\text { communications }\end{array}$ & $\begin{array}{l}\text { Brand communications function cumulatively in the } \\
\text { generation of the event's cultural capital }\end{array}$ \\
\hline $\begin{array}{l}\text { Role of music in the } \\
\text { broader experience }\end{array}$ & $\begin{array}{l}\text { Very important, but not overdetermining with regard to } \\
\text { the entire event's experiential blanket }\end{array}$ & $\begin{array}{l}\text { Most important, coupled with situational co- } \\
\text { belongingness in a globally 'in' cultural branded } \\
\text { space }\end{array}$ \\
\hline Versatility of experience & $\begin{array}{l}\text { Plethora of micro-events as destination experiential } \\
\text { micro-events }\end{array}$ & $\begin{array}{l}\text { Destination limited to attending a DJ set (on an } \\
\text { occasion-specific basis) }\end{array}$ \\
\hline $\begin{array}{l}\text { Additional experiential } \\
\text { opportunities from a } \\
\text { nomadological } \\
\text { perspective }\end{array}$ & $\begin{array}{l}\text { Practically endless, as alternative experiential pathways } \\
\text { among the existing micro-events, as well as the } \\
\text { generation of new ones given the time-span of the } \\
\text { cruise }\end{array}$ & $\begin{array}{l}\text { Temporally (each event lasts for about } 2 \mathrm{~h} \text { ) and } \\
\text { experientially limited event with limited } \\
\text { opportunities for expansion on an ad hoc basis }\end{array}$ \\
\hline
\end{tabular}

more opportunities from a nomadological point of view compared to Boiler Room as will be discussed in due course.

Consumer perceptions currently appear to be expressively constrained by the discursive folding of the events in brand communications. Rather than following the coded and territorialized avenue that is currently adopted in the events' brand communications, nomadic thinking opens up the name (brand identity) and its components (branding elements) to their affective substratum: experiencing flows of intensities that affect a pre-subjectively constituted nomad rather that a rigid structure called subject. In this context, the regimented brand architecture underlies a plethora of events-affects that await to be semanticized in individual lines-of-flight. 
With regard to Boiler Room, and in continuation of the relevant discussion in Sect. 2, club-dancing does constitute an ecstatic experience as the dancer is released from the strict contours of his selfhood while mingling with fellow dancers in a situational collective (Malbon 1999). Dancing constitutes a constant bodily reterritorialization as comingling with exteriority. At the same time, assemblages are produced in an ongoing fashion between dancers and between dancers and their surroundings. It is a constant production of hand and limbic movements that set in motion unique lines-of-flight that proliferate below the ego's radar as dancers fuse in an ecstatic experiencing. This may be said to be the mission statement of the Boiler Room, from a nomadological point of view, i.e., to produce maximum cybernetic heat whereby subjectivity is liquidated. In this predicament, the nomad is freed to produce assemblages with his surroundings, thus experiencing singularly the cultural space of the clubbing place.

Club dancers form a closed-circuit of intensity flows conditioned by the spatial contours of the club, albeit as territorial constraints, rather than experiential. "Dancing fuses notions of 'inside' (emotions) and 'outside' (motions) as the internal becomes externalised, and the external becomes internalised" (Malbon 1999, p. 91). This key aspect of dancing renders it an affective experience as encounter between the inside and the outside, a dominant perception in the Boiler Room-related literature: "There are plenty of ways to measure the value that venues can bring to an area and to a musical community, but it's the vague, slippery ideas you can't measure-like energy or a feeling-that are the most important" (Table 3 in Appendix, 50). While performing dance, clubbers negotiate their self and collective identities by tactically blending in imaginative ways with the pre-scripted set around them, involving the DJ-booth, the dance-floor, the laser-lights (Thornton 1995, p. 93), and the rest paraphernalia that make up a standard clubbing experience.

The same setting applies in the case of the live-show, whether it is performed at a club venue or at a festival or while being afloat on 70,000 Tons of Metal. However, in contrast to the territorial constraints of Boiler Room, liveshow attendance at 70,000 Tons of Metal is fundamentally unconstrained, and conditioned by the moving space of the sea. The spatial differences between 70,000 Tons of Metal and Boiler Room, in this instance, concern the global mobility of the latter and the being afloat of the former. Ultimately, this difference is resolved in both events' flows of intensity being territorially unconstrained. In the case of 70,000 Tons of Metal this is enhanced communicatively by the multinational profile of the participants: "we are one world without borders" (Table 3 in Appendix, 14). Both events are, therefore, exemplary cases of post-place branding consisting of one or more branded spaces for nomadic experiencing.

The mobility of Boiler Room is akin to being afloat in the sea (the case of 70,000 Tons of Metal), although differing in terms of predestination. The cultural space of the Boiler Room is not pre-destined. New art-forms, hybrids of existing (sedimented) genres constantly proliferate as they are discovered and as they are invented. The non-predestination of the Boiler Room, as cultural space spawning hybrid artistic forms that transpierce and punctuate established genres, may be leveraged as an ontological metaphor. This discursive form abides by the tenets of postplace branding, with a non-predestination caveat either as place (of departure/arrival) or as anchoring in a striated artistic genre, and thus as being rooted in a smooth spatiality.

Nevertheless, although in a club environment, as Malbon (1999, p. 95) stresses, "territorialisations that are bounded both spatially and temporally are always open to alternative spacings and orderings that dancing and nondancing clubbers may attempt to impose," the experiential possibilities of the Boiler Room in its current realization are significantly more constrained compared to 70,000 Tons of Metal. The latter offers a plethora of experiential microevents, complementary to the around-the-clock live-shows. 70,000 Tons of Metal's experiencing has been lucidly described in attendees' perceptions: "the urge to sleep disappears. It's like your body understands the need to live every moment and alters its chemistry in accordance" (Table 3 in Appendix, 11).

More importantly, though, flows of intensities are experienced in the encounter between the pre-individuated body and absolute exteriority as sea flow: "it's the rush of adrenaline and the ocean [...] it's that overwhelming feeling of ecstasy and excitement-child like curiosity-for every waking, coherent moment" (Table 3 in Appendix, 11). The sea as absolute exteriority allows for a constant deterritorialization of the experience. Being afloat as place conditional is almost invariably highlighted by 70,000 Tons of Metal's consumers and in the event's promotional discourse. In fact, were it not for being afloat this would have been no different than a stereotypical festival. The articulation of the experience is enacted against the spatial condition of flow, as constant deterritorialization. Deterritorialization is posited as a conditio sine qua non for the reframing of cultural space. It functions in this social text as unbounded, placeless experiencing.

In this context, goal-oriented activities, such as the aforementioned experiential micro-events, are conditioned by a constantly moving, non-replicable, uncoded becoming. The passengers are the fleet on a dreamlike cruise to the boundless and overflowing consumptive desire. Whereas traditional place branding models comprise the 
cultural ethos of a place and its rhetorical fabric (as common places), the boundlessness of experiential deterritorialization anchors the 'fleet' in a new space of coalescing overflowing intensities.

Let us explore in the following sub-section how 70,000 Tons of Metal's suppressed or latently protruding communicative space through a largely territorial chain may be transformed into a smooth one with a view to transforming monadic into nomadic experiences.

\section{Nomadologically reframing the brand communications of 70,000 Tons of Metal through metaphorical modeling}

In the previous sub-section, we saw that both events' branding discourse is largely sedimented and territorialized. Here, the branding discourse of 70,000 Tons of Metal is re-imagined alongside nomadological lines as a metaphorical modeling system.

\section{Principles of metaphorical modeling}

A metaphorical modeling system consists in creating coherence among the metaphors making up a discursive piece by ordering them in specific cultural and embodied ways (Hirschman 2007). As propounded by Lakoff and Johnson (1987), metaphorical modeling organizes a whole system of concepts with respect to one another. Thus, strategic orientation is furnished for structuring reality, making meaning (Lakoff and Johnson 1987; Hirschman 2007; Forceville 2009) and articulating a brand identity (Hanna and Rowley 2013).

For Lakoff and Johnson (1980) the modus operandi of the mind is fundamentally metaphorical. They identify three types of metaphors, orientational, structural, and ontological. Orientational metaphors structure concepts linearly (e.g., good is up); structural metaphors are responsible for structuring one kind of experience or activity in terms of another kind of experience or activity (e.g., life is a gambling game); ontological metaphors involve the projection of entity or substance status on something that does not possess that status (e.g., the mind is a container). Metaphors function through meaning transfers from a source (e.g., gambling game) to a target domain (e.g., life) (Lakoff and Johnson 2003). Linguistic properties from the source are transferred to the target object, subject, state-of-affairs. Metaphors are structured hierarchically, from super-ordinate to subordinate ones based on their relative saliency in a metaphorical modeling schema.
The metaphorical modeling exercise that is undertaken here aids especially in understanding the relational pathways among the micro-events (i.e., karaoke, movie theater) that make up 70,000 Tons of Metal (as laid out earlier in the description of 70,000 Tons of Metal's brand architecture). These micro-events constitute the experiential basis (Lakoff 1993) for furnishing simulacra (Baudrillard 1994) of event experiencing (Ritchie 2013).

In the context of 70,000 Tons of Metal's discourse I am particularly concerned with pointing out how the postplace ontological metaphor of openness to absolute exteriority as constantly being afloat may accommodate and furnish orientation to the rest experiential micro-events. The following analysis is geared towards this task.

In this context, brand communications are not merely intended to inform about the availability of micro-events, but to highlight their role as simulacra of experiential flows of intensities. This is a uniquely differentiated approach in the production of experiential meaning through the employment of linguistic or multimodal signs in general. It allows for freeing consumption experiences from the striated space of an event's symbolic discourse towards the smooth space of direct experiences where brand identities and branding components do not stand representationally for empirical objects (in the vein of place branding), but for encounters between non-striated space and the nomadic self.

This brand communicative approach is incumbent on sea flow and flows of intensities as singular becomingsother on a pre-subjective level, as pre-representational experiencing. Yet, these intensities may not be communicated in their pre-articulate non-linguistic form as pure materiality, but as part of a metaphorical edifice that is rooted in the schema of flow as absolute deterritorialization. This schema is evoked as being afloat on the sea that "carries us away towards a destination that is neither foreseeable nor pre-existent" (Hallward 2006, p. 28). Hence, we are concerned not with place branding, but with radical deterritorialization, and therefore with non-place or post-place branding.

Although the current brand discourse of 70,000 Tons of Metal leverages 'sea' and 'cruise' as parts of its unique selling proposition, it does so partially and fleetingly as parts of a communicative mode where their habitual territorialization suggests hazy benefits of escapist fun and excitement. In other words, a strategic approach that would highlight their generative role as ontological metaphors is not in place. The reinscription of these descriptors in a nomadological framework is intent on transforming them into super-ordinate ontological metaphors that encompass 
micro-events as subordinate orientation metaphors. This opening up of territorialized experiential spaces to suppressed potentialities that remain dormant at a plane of virtuality implies a constant becoming of de- and reterritorializations.

Streamlining communicatively the experiential microevents with the ontological metaphor of experiential openness

The first nomadological reframing task for 70,000 Tons of Metal's brand communications may be accomplished by streamlining communicatively the experiential microevents with the ontological metaphor of experiential openness. This is attainable by rebranding micro-events in such a manner as to contain the descriptor 'open' either as such, or through derivatives and (quasi) synonyms. An example is renaming Karaoke into 'Karaoke afloat.' Another example is rebranding pillow-fighting as an energy release session.

Furthermore, micro-events may be combined, ordered, assembled communicatively in superior clusters that reflect their temporary territorialization as experiential microdestinations within the broader 'event.' This implies uprooting the employed descriptors from striated space and delivering them to smooth space as parts of a new linguistic assemblage. For example, instead of using prosaic descriptive language such as making an experiential destination recommendation (e.g., why don't you give it up for a karaoke night?), three or more micro-events may be subsumed under an experiential itinerary that highlights the possibility of drawing one's own lines-of-flight while navigating experiential space.

Here I am citing guidelines in the context of an ad creative brief, rather than as final copy received by a copywriter: "70,000 Tons of Metal is an open-destination journey; you can carve your own path by finding your own space while being afloat; either in one of our experiential havens or by simply following your own whim as you explore combinations among temporary destinations; it's not about engaging your senses, but of letting-flow, afloat on 70,000 Tons of Metal." In this context, metaphorical modeling does not consist in identifying a property from a source domain and accommodating it under the semantic scope of a target domain while capitalizing on a common set of experiential similarities. Rather, we are concerned with assuming an ontological metaphor (being-afloat as open destination) as source domain that seethes into subordinate experiential domains and folds them in its tidal waves. In this manner, the ontological metaphor reterritorializes subordinate experiential domains onto a smooth space where their meaning and value alternate as experiential intensity flows.
Multiplying the singular assemblages between nomadic subjects and micro-events in orientation metaphors

The second nomadological reframing task, that is the proliferation of the experiential spectrum within the already available set of experiential micro-events, may be attained by multiplying the singular assemblages between nomadic subjects and micro-events. These assemblages concern either experiencing differentially individual microevents or drawing singular experiential pathways (Braidotti 2009, p. 62) among micro-events. Examples of the former as coded practices include stage-diving, mosh pit dancing, and headbanging. A re-imagined experiencing possibility within the territorial space of the live-show consists in engaging in mustard-paintball, thus combining food (unleashed from its territorialized meaning as nourishment) with the consumption of the live spectacle, both reassembled as mediated energy release or as participatory exchange of intensity flows.

\section{(Re)inventing experiential micro-events through pathways} as orientation metaphors

Finally, the third nomadological reframing task of (re)inventing experiential micro-events, indicative solutions include a leaflet that will be handed to participants by the metal brand ambassadors on board (separately from or incorporated in the current leaflet) with the performing bands and dates of appearance, featuring all experiential micro-events with pathways among them (as orientation metaphors). The actual spaces may be branded along the same lines (with indicative pathways), including floorstickers, ceiling-hangers, natural size banners, and microbanners in high-traffic micro-events (e.g., main restaurant, stages). In this context, a participant questionnaire is pivotal for gathering feedback not only as regards satisfaction from the currently offered services, but more importantly open-ended questions about what could be added or done differently.

The re-assembling potential of territorial signs and practices is truly infinite. The construal of 70,000 Tons of Metal's projected brand discourse in such a nomadologically experiencing manner that latches onto a permeating ontological metaphor (openness as being afloat), while extending multidirectionally towards subordinate orientation metaphors (as experiential actualizations from a plane of virtuality), is likely to safeguard the long-term viability of the event, repeat visitors and, ultimately, sustainable event equity. 


\section{Conclusions and recommendations for future nomadological research}

This paper introduced the perspective of post-place branding as nomadological experiencing by drawing on the conceptual armory of Deleuze and Guattari (1987). The perspective is rooted in the broader post-representationalist turn in marketing theory.

By drawing on the experiential music events of 70,000 Tons of Metal and Boiler Room, a conceptual journey (with practical implications for the design of experiential events' branding) was undertaken from coded striated space towards smooth space via the tidal waves of reterritorializations. By putting the sedimented branding discourse of the concerned events in nomadological perspective, it was shown how new lines-of-flight as communicative and experiential possibilities open up, aiming at engaging consumers at the level of 'encounters' as singular assemblages with experiential micro-events. The subsumption of this experiential nexus under a metaphorical modeling rubric was found to be capable of effecting the strategic shift from monadism to nomadism.

Nomadology seeks to make the following conceptual contributions to the extant literature on place and destination branding:

First, it reframes the meaning of an event in such a manner as to render it quite close to the true definition of 1-2-1 marketing (and even more since it adopts a presubjective orientation to experiencing as being irreducibly multiple). The meaning of an event shifts from the symbolic determinants of a brand architecture towards microevents as non-replicable and singular experiencing by individuals at the pre-cognitive level of affect.

Second, it reverses subjectivity as processing monad to nomad. The nomad is relationally, provisionally, and situationally constituted in its encounter with matter as absolute exteriority.

Third, it views the structure of experience as immersion in between absolute exteriority and pre-subjective affect, a prototypical encounter that constitutes subjectivity in the first place.

Fourth, in a similarly radical empiricist vein, it approaches place not as being pre-constituted, not even as inherently lived and interpreted space (which presupposes an interpreting subject), but as constant spacing, produced through micro-events that condition singular experiencing as lines-of-flight: "a space occupied by intensities, forces and tactile qualities, with no fixed reference point" (Deleuze and Guattari 1987, p. 479). Thus, in comparison with traditional definitions of place in place branding, nomadology favors post-place theorizing. These microevents pass under the radar of the symbolically appropriated meaning of an event by a brand architecture. This sort of experiencing is coupled with a shift from striated to smooth space by way of de- and reterritorializations.

The practical implications for place branding planning consist of viewing destination brands as open-ended: from 'the' event to infinitely configurable events/affects. Subsequently, the experience of events is approached as floating, rather than following a linear path in territorialized space. The emerging gap between singular experiencing at such a level of pre-subjective constitution and its communicability is bridged through metaphorical modeling. By virtue of adopting a metaphorical modeling schema in brand communications micro-events become communicable both as parts of a symbolic architecture (e.g., the micro-event of karaoke within the overarching event of 70,000 Tons of Metal), as well as absolutely singular pathways among symbolically pre-constituted events (carving one's one destination in an open space). Place brand planning may benefit from metaphorical modeling by subsuming the components of a brand architecture in a schema that organizes brand discourse in a hierarchical set of ontological and subordinate orientation metaphors. The aim of such schemas is to simulate the nomadological experience of events as destination brands in a post-place predicament.

Going forward, the nomadological perspective has significant potential as experiential event planning blueprint due to its inherent openness and to the systematic disruption of the rigidity that is defining of mainstream branding discourse. This is attributed to the perspective's being conceptually and pragmatically endowed with infinitely enriching a circular process that consists of inter-penetrating pre-individual flows of intensity, their constant deand reterritorialization into individuated, subjective, and collective assemblages and their communicative, expressive fixation. Along the way, brand experiences as events consisting of one or more micro-events proliferate in singular lines-of-flight. The metaphorical rendering of these events and ordering into metaphors of variable intensity may contain this constant becoming by projecting experiential pathways.

\section{Appendix}

See Table 3. 
Table 3 70,000 Tons of Metal and BR archival resources

\begin{tabular}{|c|c|c|c|c|c|}
\hline & Year & Event & $\begin{array}{l}\text { Type } \\
\text { (written } \\
\text { report/ } \\
\text { video) }\end{array}$ & Article/video title & Web link \\
\hline 1 & 2017 & 70,000 Tons of Metal & $\mathrm{r}$ & THE VOYAGE & http://70000tons.com/voyage/ \\
\hline 2 & 2017 & 70,000 Tons of Metal & $\mathrm{r}$ & SPECIAL ONBOARD EVENTS & $\begin{array}{l}\text { http://70000tons.com/voyage/special-onboard- } \\
\text { events/ }\end{array}$ \\
\hline 3 & 2017 & 70,000 Tons of Metal & $\mathrm{r}$ & $\begin{array}{l}\text { 70000TONS OF METAL POOL GIRL } \\
\text { OF THE MONTH CALENDAR }\end{array}$ & $\begin{array}{l}\text { http://70000tons.com/70000tons-of-metal-pool- } \\
\text { girl-of-the-month-calendar/ }\end{array}$ \\
\hline 4 & 2017 & 70,000 Tons of Metal & $\mathrm{r}$ & landing page 2017 & http://70000tons.com/ \\
\hline 5 & 2017 & 70,000 Tons of Metal & $\mathrm{r}$ & PRICING & 70000TONS OF METAL_PRICING \\
\hline 6 & 2017 & 70,000 Tons of Metal & $\mathrm{r}$ & deck plans & http://70000tons.com/deck-plans/ \\
\hline 7 & 2017 & 70,000 Tons of Metal & $\mathrm{r}$ & 70000 TONS OF METAL DAY 1 & $\begin{array}{l}\text { http://bravewords.com/galleries/70000-tons-of- } \\
\text { metal-day-1-boatload-of-heavyweights }\end{array}$ \\
\hline 8 & 2017 & 70,000 Tons of Metal & $\mathrm{r}$ & 70000 TONS OF METAL DAY 2 & $\begin{array}{l}\text { http://bravewords.com/galleries/70000-tons- } \\
\text { day-2-a-list-start-to-finnish }\end{array}$ \\
\hline 9 & 2017 & 70,000 Tons of Metal & $\mathrm{r}$ & 70000 TONS OF METAL DAY 3 & $\begin{array}{l}\text { http://bravewords.com/galleries/70000-tons-of- } \\
\text { metal-day-3-smoke-on-the-water }\end{array}$ \\
\hline 10 & 2017 & 70,000 Tons of Metal & $\mathrm{r}$ & 70000 TONS OF METAL DAY 4 & $\begin{array}{l}\text { http://bravewords.com/galleries/70000-tons-of- } \\
\text { metal-day-4-metal-is-like-a-box-of- } \\
\text { chocolates }\end{array}$ \\
\hline 11 & 2017 & 70,000 Tons of Metal & $\mathrm{r}$ & $\begin{array}{l}\text { Holy Ship! "Metal” Tim's } 70000 \text { Tons } \\
2017 \text { Diary - Bravewords.com }\end{array}$ & $\begin{array}{l}\text { http://bravewords.com/galleries/holy-ship- } \\
\text { metal-tims-70000-tons-2017-diary }\end{array}$ \\
\hline 12 & 2017 & 70,000 Tons of Metal & $\mathrm{v}$ & $\begin{array}{l}\text { 70000TONS OF METAL 2017: Day } 1 \\
\text { Recap }\end{array}$ & $\begin{array}{l}\text { https://www.youtube.com/watch?v= } \\
\text { vsVxT3njeB0 }\end{array}$ \\
\hline 13 & 2017 & 70,000 Tons of Metal & $\mathrm{v}$ & $\begin{array}{l}\text { 70000TONS OF METAL 2017: Day } 2 \\
\text { Recap }\end{array}$ & $\begin{array}{l}\text { https://www.youtube.com/watch?v=qv_ } \\
\text { 67fYo3tM }\end{array}$ \\
\hline 14 & 2017 & 70,000 Tons of Metal & $\mathrm{v}$ & $\begin{array}{l}\text { 70000TONS OF METAL 2017: Day } 3 \\
\text { Recap }\end{array}$ & $\begin{array}{l}\text { https://www.youtube.com/watch?v= } \\
\text { rQHvCNgLrfQ }\end{array}$ \\
\hline 15 & 2017 & 70,000 Tons of Metal & $\mathrm{v}$ & $\begin{array}{l}\text { 70000TONS OF METAL 2017: Day } 4 \\
\text { Recap }\end{array}$ & $\begin{array}{l}\text { https://www.youtube.com/watch?v= } \\
\text { i6hqKb40TDI }\end{array}$ \\
\hline 16 & 2016 & 70,000 Tons of Metal & $\mathrm{r}$ & $\begin{array}{l}\text { 70000 TONS OF METAL - } \\
\text { OVERVIEW }\end{array}$ & $\begin{array}{l}\text { http://bravewords.com/galleries/70000-tons-of- } \\
\text { metal-overview-metal-dolphins-rasta-oh-my }\end{array}$ \\
\hline 17 & 2016 & 70,000 Tons of Metal & $\mathrm{r}$ & 70000 TONS OF METAL Day 1 & $\begin{array}{l}\text { http://bravewords.com/galleries/70000-tons-of- } \\
\text { metal-day-1-lets-get-this-party-started }\end{array}$ \\
\hline 18 & 2016 & 70,000 Tons of Metal & $\mathrm{r}$ & 70000 Tons Of Metal Day 2 & $\begin{array}{l}\text { http://bravewords.com/galleries/70000-tons-of- } \\
\text { metal-day-2-if-the-boats-a-rockin }\end{array}$ \\
\hline 19 & 2016 & 70,000 Tons of Metal & $\mathrm{r}$ & 70000 Tons Of Metal Day 3 & $\begin{array}{l}\text { http://bravewords.com/galleries/70000-tons-of- } \\
\text { metal-day-3-jamaican-a-lot-of-noise-you- } \\
\text { metalheads }\end{array}$ \\
\hline 20 & 2016 & 70,000 Tons of Metal & $\mathrm{r}$ & 70000 Tons Of Metal Day 4 & $\begin{array}{l}\text { http://bravewords.com/galleries/70000-tons-of- } \\
\text { metal-fourth-quarter-super-boat-sunday }\end{array}$ \\
\hline 21 & 2016 & 70,000 Tons of Metal & $\mathrm{v}$ & $\begin{array}{l}\text { 70000TONS OF METAL 2016: Day } 2 \\
\text { Recap }\end{array}$ & $\begin{array}{l}\text { https://www.youtube.com/watch?v= } \\
\text { 4f5XMRo06bQ }\end{array}$ \\
\hline 22 & 2016 & 70,000 Tons of Metal & $\mathrm{v}$ & $\begin{array}{l}\text { 70000TONS OF METAL 2016: Day } 2 \\
\text { Recap }\end{array}$ & $\begin{array}{l}\text { https://www.youtube.com/watch?v= } \\
\text { Qj3gKD9wSOI }\end{array}$ \\
\hline 23 & 2016 & 70,000 Tons of Metal & $\mathrm{v}$ & $\begin{array}{l}\text { 70000TONS OF METAL 2016: Day } 3 \\
\text { Recap }\end{array}$ & $\begin{array}{l}\text { https://www.youtube.com/watch?v= } \\
\text { eBkVE9AwA_k }\end{array}$ \\
\hline 24 & 2016 & 70,000 Tons of Metal & $\mathrm{v}$ & $\begin{array}{l}\text { 70000TONS OF METAL 2016: Day } 4 \\
\text { Recap }\end{array}$ & $\begin{array}{l}\text { https://www.youtube.com/watch?v= } \\
\text { tGZYRAGvHII }\end{array}$ \\
\hline 25 & 2015 & 70,000 Tons of Metal & $\mathrm{r}$ & $\begin{array}{l}\text { Four Reasons 70,000 TONS OF METAL } \\
\text { Remains The Best Metal Cruise }\end{array}$ & $\begin{array}{l}\text { http://www.metalinjection.net/70000-tons- } \\
\text { metal/four-reasons-70000-tons-of-metal- } \\
\text { remains-the-best-metal-cruise }\end{array}$ \\
\hline 26 & 2015 & 70,000 Tons of Metal & $\mathrm{r}$ & 70,000 Tons of Metal 2015 Recap & $\begin{array}{l}\text { http://www.popmatters.com/post/190269- } \\
\text { blood-and-thunder-70000-tons-of-metal- } \\
\text { 2015-recap-and-blind-guardians/ }\end{array}$ \\
\hline
\end{tabular}


Table 3 continued

\begin{tabular}{|c|c|c|c|c|c|}
\hline & Year & Event & $\begin{array}{l}\text { Type } \\
\text { (written } \\
\text { report/ } \\
\text { video) }\end{array}$ & Article/video title & Web link \\
\hline 27 & 2015 & 70,000 Tons of Metal & $\mathrm{r}$ & $\begin{array}{l}\text { PRESS FEATURES } 2015 \text { _ } 70000 \text { TONS } \\
\text { OF METAL - The World's Biggest } \\
\text { Heavy Metal Cruise }\end{array}$ & $\begin{array}{l}\text { http://70000tons.com/history/press-features- } \\
\text { 2015/ }\end{array}$ \\
\hline 28 & 2015 & 70,000 Tons of Metal & $\mathrm{r}$ & 70000 TONS OF METAL 2015 PART I & $\begin{array}{l}\text { http://bravewords.com/features/70000-tons-of- } \\
\text { metal-2015-part-i-bloodlust-bongs-and- } \\
\text { birthdays-on-the-caribbean-sea }\end{array}$ \\
\hline 29 & 2015 & 70,000 Tons of Metal & $\mathrm{r}$ & 70000 TONS OF METAL - DAY 2 & $\begin{array}{l}\text { http://bravewords.com/features/70000-tons-of- } \\
\text { metal-day-2-tgif-thank-god-its-fosters }\end{array}$ \\
\hline 30 & 2015 & 70,000 Tons of Metal & $\mathrm{r}$ & 70000 TONS OF METAL - DAY 3 & $\begin{array}{l}\text { http://bravewords.com/features/70000-tons-of- } \\
\text { metal-day-3-seafood-red-stripes-on-jamaican- } \\
\text { beach }\end{array}$ \\
\hline 31 & 2015 & 70,000 Tons of Metal & $\mathrm{r}$ & 70000 TONS OF METAL: DAY 4 & $\begin{array}{l}\text { http://bravewords.com/features/70000-tons-of- } \\
\text { metal-day-4-put-the-camera-away-and-lets- } \\
\text { play }\end{array}$ \\
\hline 32 & 2015 & 70,000 Tons of Metal & $\mathrm{r}$ & $\begin{array}{l}\text { VENOM - GIVING THE MIDDLE } \\
\text { FINGER TO THE CHURCH }\end{array}$ & $\begin{array}{l}\text { http://bravewords.com/features/venom-giving- } \\
\text { the-middle-finger-to-the-church }\end{array}$ \\
\hline 33 & 2015 & 70,000 Tons of Metal & $\mathrm{v}$ & $\begin{array}{l}\text { 70000TONS OF METAL 2015: Day } 1 \\
\text { Recap on 70000TONS.TV }\end{array}$ & $\begin{array}{l}\text { https://www.youtube.com/watch?v= } \\
\text { nLaAuvHIxk4 }\end{array}$ \\
\hline 34 & 2015 & 70,000 Tons of Metal & $\mathrm{v}$ & $\begin{array}{l}\text { 70000TONS OF METAL 2015: Day } 2 \\
\text { Recap on 70000TONS.TV }\end{array}$ & $\begin{array}{l}\text { https://www.youtube.com/watch?v= } \\
\text { eeFIVnc3K6g }\end{array}$ \\
\hline 35 & 2015 & 70,000 Tons of Metal & $\mathrm{v}$ & $\begin{array}{l}\text { 70000TONS OF METAL 2015: Day } 3 \\
\text { Recap on 70000TONS.TV }\end{array}$ & $\begin{array}{l}\text { https://www.youtube.com/watch?v= } \\
\text { CC2xNBOPYSw }\end{array}$ \\
\hline 36 & 2015 & 70,000 Tons of Metal & $\mathrm{v}$ & $\begin{array}{l}\text { 70000TONS OF METAL 2015: Day } 4 \\
\text { Recap on 70000TONS.TV }\end{array}$ & $\begin{array}{l}\text { https://www.youtube.com/watch?v= } \\
\text { hvFAOQTvRME }\end{array}$ \\
\hline 37 & 2016 & BOILER ROOM & $\mathrm{r}$ & Carnival & https://boilerroom.tv/carnival/ \\
\hline 38 & 2017 & BOILER ROOM & $\mathrm{r}$ & Budweiser sponsored events & $\begin{array}{l}\text { https://boilerroom.tv/budweiser-whats-brewing- } \\
\mathrm{in} /\end{array}$ \\
\hline 39 & 2017 & BOILER ROOM & $\mathrm{r}$ & Google pixel & $\begin{array}{l}\text { https://boilerroom.tv/boiler-room-x-google- } \\
\text { pixel/ }\end{array}$ \\
\hline 40 & 2017 & BOILER ROOM & $\mathrm{v}$ & $\begin{array}{l}\text { Boiler Room \& Google Pixel - VR } \\
\text { Dancefloors: Techno in Berlin }\end{array}$ & $\begin{array}{l}\text { https://www.youtube.com/watch?v= } \\
\text { qg828p81C_c }\end{array}$ \\
\hline 41 & 2017 & BOILER ROOM & $\mathrm{v}$ & $\begin{array}{l}\text { Boiler Room \& Google Pixel - VR } \\
\text { Dancefloors: Techno in Berlin } 360 \\
\text { Film }\end{array}$ & $\begin{array}{l}\text { https://www.youtube.com/watch?v= } \\
\text { ptbGAKzZil4 }\end{array}$ \\
\hline 42 & 2017 & BOILER ROOM & $\mathrm{r}$ & Ray-Ban & https://boilerroom.tv/ray-ban/ \\
\hline 43 & 2017 & BOILER ROOM & $\mathrm{r}$ & Ballantine's & http://truemusic.boilerroom.tv/ \\
\hline 44 & 2017 & BOILER ROOM & $\mathrm{r}$ & Stay True archive & $\begin{array}{l}\text { http://truemusic.boilerroom.tv/seth-troxler/seth- } \\
\text { russia/sofia-rodina\# }\end{array}$ \\
\hline 45 & 2017 & BOILER ROOM & $\mathrm{r}$ & Barbican & https://boilerroom.tv/barbican/ \\
\hline 46 & 2017 & BOILER ROOM & $\mathrm{r}$ & Audi untaggable & https://boilerroom.tv/session/untaggable/ \\
\hline 47 & 2017 & BOILER ROOM & $\mathrm{r}$ & Adidas & $\begin{array}{l}\text { https://boilerroom.tv/recording/in-stereo-nosaj- } \\
\text { thing/ }\end{array}$ \\
\hline 48 & 2017 & BOILER ROOM & $\mathrm{r}$ & $\begin{array}{l}\text { Live bands (Azymouth, Joe Bataan, Keiji } \\
\text { Haino, Air, etc.) }\end{array}$ & https://boilerroom.tv/channel/4/ \\
\hline 49 & 2017 & BOILER ROOM & $\mathrm{r}$ & Youtube page & https://www.youtube.com/user/brtvofficial \\
\hline 50 & 2017 & BOILER ROOM & $\mathrm{r}$ & $\begin{array}{l}\text { (A Good) Space is the Place } \\
\text { Appreciating the London Club Space - } \\
\text { BOILER ROOM }\end{array}$ & https://boilerroom.tv/a-good-space-is-the-place/ \\
\hline 51 & 2017 & BOILER ROOM & $\mathrm{r}$ & $\mathrm{BR}$ articles & https://boilerroom.tv/category/features/articles/ \\
\hline
\end{tabular}


Table 3 continued

\begin{tabular}{|c|c|c|c|c|c|}
\hline & Year & Event & $\begin{array}{l}\text { Type } \\
\text { (written } \\
\text { report/ } \\
\text { video) }\end{array}$ & Article/video title & Web link \\
\hline 52 & 2017 & BOILER ROOM & $\mathrm{r}$ & London aesthetic & $\begin{array}{l}\text { https://boilerroom.tv/beyond-a-bpm-the- } \\
\text { london-aesthetic/ }\end{array}$ \\
\hline 53 & 2017 & BOILER ROOM & $\mathrm{v}$ & Boiler Room: Beyond a BPM (Part 1) & $\begin{array}{l}\text { https://www.youtube.com/watch?v= } \\
\text { HNu4VyOHA6w }\end{array}$ \\
\hline 54 & 2017 & BOILER ROOM & $\mathrm{v}$ & Boiler Room: Beyond a BPM (Part 2) & $\begin{array}{l}\text { https://www.youtube.com/watch?v= } \\
\text { 81O1BqahZho }\end{array}$ \\
\hline
\end{tabular}

\section{References}

Abousnnouga, G., and D. Machin. 2011. The Changing Spaces of War Commemoration: A Multimodal Analysis of the Discourses of British Monuments. Social Semiotics 21 (2): 175-196.

Anholt, S. 2010. Definitions of Place Branding: Working Towards a Resolution. Place Branding and Public Diplomacy 6 (1): 1-10.

Arnould, E., and L. Price. 1993. River Magic: Extraordinary Experience and the Extended Service Encounter. Journal of Consumer Research 20: 24-45.

Arrigo, Y. 2017. Festivals 2025: An Experiential Landscape. Event Special Report, Haymarket Media Group.

Ashworth, G. 2009. The Instruments of Place Branding: How Is It Done? European Spatial Research and Policy 16 (1): 9-22.

Askegaard, S., and G. Ger. 1998. Product-Country Images: Towards a Contextualized Approach. European Advances in Consumer Research 3: 50-58.

Askegaard, S. 2010. Experience Economy in the Making: Hedonism, Play and Coolhunting in Automotive Song Lyrics. Consumption Markets \& Culture 13 (4): 351-371.

Baker, B. 2007. Destination Branding for Small Cities: The Essentials for Successful Place Branding. London: Creative Leap.

Balakrishnan, M.S., and G. Kerr. 2013. The 4d Model of Place Brand Management. In Branded Spaces: Experience Enactments and Entanglements, ed. S. Sonnenburg, and L. Baker, 31-42. Amsterdam: Springer.

Baudrillard, J. 1994. Simulation and Simulacra. Michigan: Michigan University Press.

Bjerrisgaard, S.M., D. Kjeldgaard, and A. Bengtsson. 2012. Consumer-Brand Assemblages in Advertising Practices-An Analysis of Skin, Identity and Tattoos in Ads. Consumption, Markets \& Culture. https://doi.org/10.1080/10253866.2012.738067.

Boyns, D. 2006. Emotion-Based Self Theory. In Handbook of the Sociology of Emotions, ed. J.E. Stets, and J. Turner, 254-275. Amsterdam: Springer.

Braidotti, R. 2009. Nomadic Theory. New York: Columbia University Press.

Brakus, J.J. 2008. Embodied Cognition, Affordances and Mind Modularity: Using Cognitive Science to Present a Theory of Consumer Experiences. In Handbook on Brand and Experience Management, ed. B.H. Schmitt, and D.L. Rogers, 144-162. Cheltenham: Edward Elgar.

Brakus, J.J., B.H. Schmitt, and L. Zarantonello. 2009. Brand Experience: What Is It? How Is It Measured? Does It Affect Loyalty? Journal of Marketing 73 (3): 52-68.

Brennan, T. 2004. The Transmission of Affect. London: Cornwell University Press.

Campelo, A. 2015. Rethinking Sense of Place: Sense of One and Sense of Many. In Rethinking Place Branding: Comprehensive
Brand Development for Cities and Regions, ed. M. Kavaratzis, G. Warnaby, and G.J. Ashworth, 51-60. London: Springer.

Canniford, R., and D. Bajde. 2016. ASSEMBLING Consumption. In Assembling Consumption: Researching Actors, Networks And Markets, ed. R. Canniford, and D. Bajde, 1-19. Oxon: Routledge.

Caru, A., and B. Cova. 2003. Revisiting Consumption Experience: A More Humble But Complete View of the Concept. Marketing Theory 3 (2): 267-286.

Da Silva Oliveira, E.H. 2016. Place Branding as a Strategic Spatial Planning Instrument: A Theoretical Framework to Branding Regions with References to Northern Portugal. Journal of Place Management and Development 9 (1): 47-72.

Delanda, M. 2006a. Deleuzian Social Ontology and Assemblage Theory. In Deleuze and the Social, ed. M. Fuglsang, and B.M. Sørensen, 250-266. Edinburgh: University of Edinburgh Press.

Delanda, M. 2006b. A New Philosophy of Society. London: Continuum.

Deleuze, G., and F. Guattari. 1987. A Thousand Plateaus: Capitalism and Schizophrenia. Minneapolis: University of Minnesota Press.

Dholakia, N., and I. Reyes. 2013. Virtuality as Place and Process. Journal of Marketing Management 29: 1580-1591.

Dinnie, K. 2004. Place Branding: Overview of an Emerging literature. Place Branding and Public Diplomacy 1 (1): 106-110.

Egan, D. 2006. Resistance Under the Black Light Exploring the Use of Music in Two Exotic Dance Clubs. Journal of Contemporary Ethnography 35 (2): 201-219.

Fairclough, N. 2004. Analysing Discourse: Textual Analysis For Social Research. London: Routledge.

Firat, F., and A. Venkatesh. 1995. Postmodernism and the Reenchantment of Consumption. Journal of Consumer Research 22 (3): 239-267.

Firat, F., S. Pettigrew, and R.W. Belk. 2011. Themed Experiences and Spaces. Consumption Markets \& Culture 14 (2): 123-124.

Forceville, C. 2009. Non-verbal and Multimodal Metaphor in a Cognitivist Framework: Agendas for Research. In Multimodal Metaphor, ed. C.J. Forceville, and E. Urios-Aparisi, 19-44. Berlin: Mouton de Gruyter.

Fournier, S., M.R. Solomon, and B.G. Englis. 2008. When brands resonate. In Handbook on Brand and Experience Management, ed. B.H. Schmitt, and D.L. Rogers, 35-57. Cheltenham: Edward Elgar.

Fredriksen, A. 2014. Assembling Value(s): What a Focus on the Distributed Agency of Assemblages can Contribute to the Study of Value. LCSV Working Paper Series.

Govers, R., and F. Go. 2009. Place Branding: Glocal, Virtual and Physical Identities, Constructed, Imagined and Experienced. London: Palgrave.

Gustaffson, C. 2015. Sonic Branding: A Consumer-Oriented Literature Review. Journal of Brand Management 22 (1): 20-37. 
Hallward, P. 2006. Deleuze and the Philosophy of Creation. New York: Verso.

Hankinson, G. 2009. Managing Destination Brands: Establishing a Theoretical Foundation. Journal of Marketing Management 25 (1/2): 97-115.

Hankinson, G. 2015. Rethinking the Place Branding Construct. In Rethinking Place Branding: Comprehensive Brand Development for Cities and Regions, ed. M. Kavaratzis, G. Warnaby, and G.J. Ashworth, 13-31. London: Springer.

Hanna, S., and J. Rowley. 2011. Towards a Strategic Place BrandManagement Model. Journal of Marketing Management 27 (5-6): 458-476

Hanna, S., and J. Rowley. 2013. A Practitioner-Led Strategic Place Brand-Management Model. Journal of Marketing Management 29 (15-16): 1782-1815.

Hesmondhalgh, D. 2008. Towards a Critical Understanding of Music, Emotion and Self-Identity. Consumption Markets \& Culture 11 (4): $329-343$.

Hess-Luttich, E.W.B. 2016. Urban Discourse-City Space, City Language, City Planning: Eco-semiotic Approaches to the Discourse Analysis of Urban Renewal. Sign Systems Studies 44 (1/2): 12-33

Hill, T., R. Canniford, and J. Mol. 2014. Non-representational Marketing Theory. Marketing Theory 14 (4): 377-394.

Hirschman, E.C. 2007. Metaphor in the Marketplace. Marketing Theory 7 (3): 227-248.

Hogg, M., and E. Banister. 2000. The Structure and Transfer of Cultural Meaning: A Study of Young Consumers and Pop Music. Advances in Consumer Research 27: 19-23.

Holbrook, M.B., and E.C. Hirschman. 1982. The Experiential Aspects of Consumption: Consumer Fantasies, Feelings, and Fun. Journal of Consumer Research 9: 132-140.

Holbrook, M.B. 2008. Music Meanings in Movies: The Case of the Crime-Plus-Jazz Genre. Consumption Markets \& Culture 11 (4): 307-327.

Hung, K. 2001. Framing Meaning Perceptions with Music: The Case of Teaser Ads. Journal of Advertising XXX (3): 39-49.

Hughes, J. 2008. Deleuze and the Genesis of Representations. London: Continuum.

Jackson, D.M. 2003. Sonic Branding: An Introduction. New York: Palgrave-Macmillan.

Kavaratzis, M., and A. Kalandides. 2015. Rethinking the Place Brand: The Interactional Formation of Place Brands and the Role of Participatory Place Branding. Environment and Planning 47 (6): 1368-1382.

Kitchen, P. (ed.). 2008. Marketing Metaphors and Metamorphosis. London: Palgrave.

Kotarba, J.A. 2003. Review Essay: Popular Music and Everyday Life: Three Styles of Scholarly Appreciation. Journal of Contemporary Ethnography 32: 360-368.

Lagopoulos, A.P. 2009. The Social Semiotics of Space: Metaphor, Ideology, and Political Economy. Semiotica 173 (1/4): 169-213.

Lakoff, G. 1993. The Contemporary Theory of Metaphor. In Metaphor and Thought, ed. D. Ortony, 202-251. Cambridge: Cambridge University Press.

Lakoff, G., and M. Johnson. 1980. The Metaphorical Structure of the Human Conceptual System. Cognitive Science 4: 195-208.

Lakoff, G., and M. Johnson. 2003. Metaphors We Live By. Chicago: The University of Chicago Press.

Latour, B. 2005. Reassembling the Social: An Introduction to ActorNetwork Theory. Oxford: Oxford University Press.

Lichrou, M., L. O'Malley, and M. Patterson. 2014. On the Marketing Implications of Place Narratives. Journal of Marketing Management 30 (9-10): 832-856.
Lorraine, T. 2005. Ahab and Becoming-Whale: The Nomadic Subject in Smooth Space. In Deleuze and Space, ed. I. Buchanan, and G. Lambert, 159-175. Edinburgh: Edinburgh University Press.

Malbon, B. 1999. Clubbing: Dancing, Ecstasy and Vitality. London: Routledge.

Massumi, B. 1996. A Reader's Guide to Capitalism and Schizophrenia: Deviations from Deleuze \& Guattari. Cambridge, MA: MIT Press.

Massumi, B. 2002. Parable for the Virtual: Movement, Affect, Sensation. Durham: Duke University Press.

McIlvenny, P., and C. Noy. 2011. MULTIMODAL Discourse in Mediated Spaces. Social Semiotics 21 (2): 147-154.

Moilanen, T., and S. Rainisto. 2009. How to Brand Nations, Cities and Destinations: A Planning Book for Place Branding. London: Palgrave.

Morgan, N., A. Pritchard, and R. Pride (eds.). 2011. Destination Brands: Managing Place Reputation. Amsterdam: Elsevier.

Ober-Heilig, N., S. Bekmeier-Feuerhahn, and J. Sikkenga. 2014. Enhancing Museum Brands with Experiential Design to Attract Low-Involvement Visitors. Arts Marketing: An International Journal 4 (1/2): 67-86.

Organ, N., A. Pritchard, and R. Pride (eds.). 2011. Destination Branding: Creating the Unique Destination Proposition. Oxford: Butterworth-Heinemann.

Parr, A. 2010. The Deleuze Dictionary. Edinburgh: Edinburgh University Press.

Patton, P. 2005. Freedom. In The Deleuze Dictionary, ed. A. Parr, 117-119. Edinburgh: Edinburgh University Press.

Pine, J.B., and J.H. Gilmore. 1998. Welcome to the Experience Economy. Harvard Business Review 76 (4): 97-105.

Ritchie, D.L. 2013. Metaphor. Cambridge: Cambridge University Press.

Rokka, J., and R. Canniford. 2016. Heterotopian Selfies: How Social Media Destabilizes Brand Assemblages. European Journal of Marketing 50 (9/10): 1-29.

Rossolatos, G. 2013. A Methodological Framework for Conducting Multimodal Rhetorical Analyses of Advertising Films with ATLAS.ti. In Atlas.ti User Conference 2013: Fostering Dialog on Qualitative Methods, ed. S. Friese, and Y. Ringmayr, 1-52. Berlin: Berlin Technical University Press. http://papers.ssrn. com/sol3/papers.cfm?abstract_id=2315566.

Rossolatos, G. 2014. Lady Gaga as (Dis)simulacrum of Monstrosity. Celebrity Studies 6 (2): 231-246.

Rossolatos, G. 2015a. Servicing a Heavy Metal Fandom Posthumously: A Sociosemiotic Account of Collective Identity Formation in Dio's Memorial. Social Semiotics 25 (5): 633-655.

Rossolatos, G. 2015b. Taking the "Multimodal Turn" in Interpreting Consumption Experiences. Consumption, Markets \& Culture 18 (5): 427-446.

Rossolatos, G., and M. K. Hogg. 2013. Fetish, Taboo, Simulacrum: An Applied Psychoanalytic/Semiotic Approach to the Experiential Consumption of Music Products. Proceedings of the 12th International Marketing Trends Conference, Paris, France, 17-19 January. http://www.marketing-trendscongress.com/ archives/2013/pages/PDF/770.pdf.

Smilansky, S. 2009. Experiential Marketing: A Practical Guide to Interactive Brand Experiences. London: Kogan Page.

Sonnenburg, S., and L. Baker. 2013. Approaching Branded Spaces. In Branded Spaces: Experience Enactments and Entanglements, ed. S. Sonnenburg, and L. Baker, 9-30. Amsterdam: Springer.

Spiggle, S. 1994. Analysis and Interpretation of Qualitative Data in Consumer Research. Journal of Consumer Research 21 (3): 491-503.

Thompson, C.J., W. Locander, and H.R. Pollio. 1990. Putting Consumer Experience Back into Consumer Research: The 
Philosophy and Method of Existential Phenomenology. Journal of Consumer Research 16: 133-146.

Thornton, S. 1995. Club Cultures: Music, Media and Subcultural Capital. Cambridge: Polity.

Voisset-Veysseyre, C. 2011. Toward a Post-Identity Philosophy: Along a Flight Line with Gilles Deleuze. Trahir 2: 1-18.

Zaltman, G., and L.H. Zaltman. 2008. Marketing Metaphoria: What Deep Metaphors Reveal About The Minds Of Consumers. Massachusetts: Harvard University Press.

Zenker, S., and E. Braun. 2017. Questioning a "One Size Fits All" City Brand: Developing a Branded House Strategy for Place Brand Management. Journal of Place Management and Development 10 (3): 270-287.

George Rossolatos (MSc, MBA, PhD) is an academic researcher, marketing practitioner, and the editor of the International Journal of Marketing Semiotics (Department of English, Kassel University,
Germany). Major publications include the Handbook of Brand Semiotics (2015; ed. and co-author), Semiotics of Popular Culture (2015), Brand Equity Planning with Structuralist Rhetorical Semiotics $(2012,2014), / /$ rhetor.dixit//: Understanding ad texts' rhetorical structure for differential figurative advantage (2013), Applying Structuralist Semiotics to Brand Image Research (2012), Interactive Advertising: Dynamic Communication in the Information Age (2002; ed. and co-author), plus numerous articles in trade and academic journals. His research interests focus on cultural consumer research/ popular culture, branding/advertising, new media, and span various disciplines such as rhetoric, semiotics, phenomenology, deconstruction, psychoanalysis, communication theory. 